MEDICINE AND THE LAW

\title{
Can children aged 12 years or more refuse life-saving treatment without consent or assistance from anyone else?
}

\author{
D J McQuoid-Mason \\ David McQuoid-Mason is Professor of Law at the Centre for Socio-Legal Studies, University of KwaZulu-Natal, Durban, and publishes and teaches \\ in medical law.
}

Corresponding author: D J McQuoid-Mason (mcquoidm@ukzn.ac.za)

The question of whether a child aged 12 years or more who is sufficiently mature and has the necessary mental capacity may refuse to consent to life-saving treatment without consent from a parent, guardian or caregiver or without the assistance of a parent or guardian is governed by the Constitution, the Children's Act, the National Health Act and the common law. The best interests of the child are paramount, and should the child unreasonably refuse to consent to life-saving treatment, the Minister of Social Development may give consent for such treatment in terms of the Children's Act. Otherwise, should a parent, guardian, caregiver or healthcare provider believe that such a refusal is not in the best interests of the child, he or she may approach the High Court for an order to provide such treatment.

S Afr Med J 2014;104(7):466-467. DOI:10.7196/SAMJ.8417

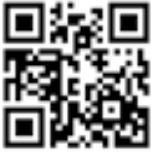

The Children's Act ${ }^{[1]}$ provides that a child who: $(i)$ is 12 years of age or older; (ii) is of sufficient maturity; and (iii) has the mental capacity to understand the benefits, risks, social and other implications of the treatment may consent to medical treatment without consent from a parent, guardian or caregiver or the assistance of a parent or guardian (section 129(2)). However, the question arises whether a child may refuse to consent to life-saving medical treatment without such consent or assistance. In order to answer this question, it is necessary to consider the provisions of the Constitution $^{[2]}$ (chapter 2), the Children's Act ${ }^{[1]}$ (section 129(2)), the National Health $\mathrm{Act}^{\left[{ }^{3]}\right.}$ (section 6(1)(d)) and the common law.

\section{Constitutional provisions regarding children}

The Constitution ${ }^{[2]}$ defines a child as a person under 18 years of age (section 28(3)) and lists the rights that are specially given to children (section 28(1)), apart from the other rights that also apply to them, such as the right to dignity (section 10), the right to life (section 11), the right to bodily and psychological integrity (section 12(2)) and the right to privacy (section 14). However, the most important provision in the Bill of Rights that affects children states: 'A child's best interests are of paramount importance in every matter concerning the child' (section 28(2)). What is a 'child's best interests' is not defined in the Constitution, but may be interpreted by reference to the Children's Act and the common law.

\section{The Children's Act and the 'best interests of the child'}

The relevant provisions of the Children's Act ${ }^{[1]}$ state that a child's best interests are 'of paramount importance' (section 9), and set out the 'best interests of the child standard', which requires, among other things, that the following be taken into account: (i) the child's age, maturity and stage of development, gender, background, and any other relevant characteristics; (ii) the child's physical and emotional security and his or her intellectual, emotional, social and cultural development; (iii) any disability that the child may have; and (iv) any chronic illness from which the child may suffer (section $7(1)$ ). The Act goes on to say that a child with a disability or chronic illness has the right not to be subjected to medical, social, cultural or religious practices that are detrimental to his or her health, wellbeing or dignity (section 11(3)). The relevant factors listed in the Act for assessing the best interests of the child standard may assist a healthcare provider in deciding whether a child of 12 years of age or more is 'of sufficient maturity' and has the necessary 'mental capacity' to give informed consent. The provision regarding disability and chronic illness implies that such a child may refuse to be subjected to medical treatment that is detrimental to his or her dignity - which is also a constitutional imperative ${ }^{[2]}$ (section 10).

\section{The Children's Act and consent to medical treatment by children}

As previously mentioned, the Children's Act ${ }^{[1]}$ provides that a child over the age of 12 years who is sufficiently mature and who has the mental capacity to understand the benefits, risks and social and other implications of the treatment, may consent to medical treatment on their own (section 129(2)). There is no need for consent by a parent, guardian or caregiver or for assistance from a parent or guardian, unlike in the case of surgical operations, where the assistance of a parent or guardian is required (section 129(3)). The consent of a parent, guardian or caregiver is required in the case of persons who are under 12 years of age, or who are 12 years of age but do not have the necessary maturity or mental capacity (section 129(4)).

The Children's Act ${ }^{[1]}$ does not mention refusal of consent by children, apart from the implication regarding children who suffer from a disability or chronic illness (section 11(3)). The Act provides, however, that the Minister of Social Development may consent to medical treatment of a child if the child unreasonably refuses to 
give consent' (section 129(8)). When deciding the reasonableness or otherwise of the child's refusal, the Minister should judge it against the best interests of the child standard. In any event, the Act does not exclude the inherent jurisdiction of the High Court as the upper guardian of all children (section 45(4)), and the Court can always be approached as a last resort to ensure that decisions are made in the best interests of the child.

The other legal principles relevant to refusal of life-saving medical treatment by children are to be found in the National Health $\mathrm{Act}^{[3]}$ (section 6(1)(d)) and the common law.

\section{National Health Act provisions dealing with refusal of consent to medical treatment}

The National Health Act ${ }^{[3]}$ (section 6(1)(d)) requires health providers to inform users (patients) about their right to refuse health services, and also requires them to explain the implications, risks and obligations of such refusal. These requirements are not very different from what is contained in the 'mental capacity' necessary for 12-yearold children to consent to treatment, as they need to 'understand the benefits, risks, social and other implications of the treatment ${ }^{\left[{ }^{[1]}\right.}$ (section 129(2)). Therefore, if the child is able to understand these implications, the refusal to consent will have to be given by a parent, guardian or caregiver ${ }^{[1]}$ (section 129(4)).

Health providers can test the child's ability to understand the consequences of refusal of consent by explaining the implications to the child in simple language and then getting the child to paraphrase what has been explained. It may be necessary to explain the implications more than once before testing the child's understanding in order to avoid making a hasty determination of the child's ability to give an informed refusal of consent.

\section{The common law and refusal of consent to medical treatment}

The common law has to be developed in line with 'the spirit, purport and objects of the Bill of Rights ${ }^{[2]}$ (section 39(2)). The common law principle that patients may refuse life-saving medical treatment is echoed in the provisions of the National Health $\mathrm{Act}^{[3]}$ (section 6(1)(d)) and should be developed in line with the constitutional provisions ${ }^{[2]}$ regarding the rights to dignity (section 10), life (section 11 ), bodily and psychological integrity (section 12(2)) and privacy (section 14). In the case of children, the common law also has to ensure that the best interests of the child are paramount (section 14).
The right to dignity means that patients have the right to have their dignity respected and protected if they feel that medical treatment will subject them to infringements of their dignity ${ }^{[2]}$ (section 10). This may occur when invasive medical treatment that subjects the patient to indignity is used to preserve the patient's life in situations where the prognosis is hopeless and has been continued despite a request by the patient that it be stopped. Such conduct would likewise violate the patient's rights to bodily and psychological integrity (section 12(2)) and privacy (section 14), and the health providers concerned would be acting unethically and illegally as their conduct would amount to an assault on the patient. ${ }^{[4]}$

The right to life implies that a person may end his or her own life although the common law does not allow a third person to take active steps to end another person's life. ${ }^{[5]}$ The common law does, however, recognise that it is not unlawful to withhold or withdraw medical treatment where a patient of sound mind has made that request or has made an advance directive (e.g. a living will). ${ }^{[6]}$

\section{Conclusion}

In the light of the above discussion about the effect of the Constitution, the Children's Act, the National Health Act and the common law, provided $\mathrm{s} / \mathrm{he}$ is sufficiently mature and has the necessary mental capacity $^{[1]}$ (section $129(2)$ ), a child aged 12 years or more may refuse to consent to life-saving treatment without consent from a parent, guardian or caregiver and without the assistance of a parent or guardian.

Should the child 'unreasonably refuse' to consent to life-saving treatment, the Minister of Social Development may give consent for such treatment in terms of the Children's Act ${ }^{[1]}$ (section 129(8)). Alternatively, should a parent, guardian or caregiver - or indeed a healthcare provider - believe that such a refusal is not in the best interests of the child, he or she may approach the High Court for an order to provide such treatment.

\footnotetext{
South African Government. The Children's Act No. 38 of 2005. Pretoria: Government Printer, 2005. http://www.justice.gov.za/legislation/acts/2005-038\%20childrensact.pdf (accessed 15 April 2014).

2. South African Government. The Constitution of the Republic of South Africa 1996. Pretoria: Government Printer, 1996. www.thehda.co.za/uploads/images/unpan005172.pdf (accessed 15 April 2014).

3. South African Government. The National Health Act No. 61 of 2003. Pretoria: Government Printer, 2005. http://www.saflii.org/za/legis/consol_act/nha-2003147/pdf (accessed 15 April 2014). Cf. Esterhuizen v Administrator, Transvaal 1957 (3) SA 710 (T).

5. S v Hartmann 1975 (3) SA 532 (C).

6. Currie I, de Waal J. The Bill of Rights Handbook. 5th ed. Cape Town: Juta \& Co, 2006:289.
} 